\title{
EARLY MODERN SCOTISTS AND THOMISTS ON THE QUESTION ON THE INTELLECT'S FIRST AND ADEQUATE OBJECT $\left(15^{\mathrm{TH}}-17^{\mathrm{TH}}\right.$ CENTURIES)*
}

\author{
Anna Tropia \\ Karlova Univerzita, Praha
}

\section{Resumen}

Se analizan las críticas de los escotistas del s. XVII a los comentadores de tomistas que reflexionaron sobre el primer objeto del intelecto y la extensión del conocimiento humano, que Tomás de Aquino había planteado en la Summa theologiae. No obstante, a partir del s. XV, estos comentadores ya habían comenzado a integrar los planteamientos de Escoto.

\section{Palabras clave}

Primer objeto del intelecto; comentadores de Tomás de Aquino; escotistas de la primera modernidad; conocimiento humano.

\begin{abstract}
This paper analyses the criticisms put forward by the Scotists of the 17th century to Thomas Aquinas' commentators on the subject of the intellect's first object. What the intellect knows first, and what the extension of human cognition is, are questions that Aquinas addressed in several places in Summa theologiae, presenting conclusions which Scotus famously criticised. From the 15th century on, observed the tendency among Aquinas' commentators to adjust
\end{abstract}

* This work was supported by the European Regional Development Fund-Project «Creativity and Adaptability as Conditions of the Success of Europe in an Interrelated World» (No. CZ.02.1.01/0.0/0.0/16_019/0000734). I also wish to express my gratitude to Serena Masolini, Fabio Zinelli, Ada Bronowski, as well as to the two blind reviewers who helped me improve the quality of this paper. As to references: all quotations from Aquinas are made from the Opera Omnia Vaticana; cf. Sancti Thomae de Aquino, Opera Omnia, iussu impensaque Leonis XIII edita, Romae, ex typographia Poliglotta, 1888. The quotations from Duns Scotus are made from the Wadding edition: see Johannes Duns Scotus, Opera Omnia, Reprografischer Nackdruck der Ausgabe Lyon, 1639, Hildesheim, Georg Olms Verlagsbuchhandlung, 1968. Henceforth quotations from Scotus will be made under this form: Duns Scotus, Work, Wadding, followed by the number of the volume and the page (i.e.: Wadding X p. 200). 
themselves to Scotus' opinion concerning this matter. The paper includes a collection of the texts they mention and focuses on this 'shift' in the history of Aquinas' readings.

\section{Keywords}

Intellect's first object; Thomas Aquinas' commentators; early modern Scotists; human cognition

\section{The intellect's first and adequate object}

Medieval philosophers used to call «adequate» to a cognitive power the object which that power is able to know directly and first, without the involvement of any other power: the most common example given by scholastics is the one of colour, which is sight's first object, or sound, which is hearing's first object. The adequate object thus designates a cognitive power's extension. In Aquinas' account of cognition, the question of the intellect's first and adequate object fixes the limits of the created mind's capacity. At the core of his argument, there is the idea that the cognitive faculty's nature determines its cognitive object. The philosopher assigns to different intellects - such as the enmattered, human intellect, or that which is separate from matter, the angelic intellect- a precise range of knowledge, dictated by its nature and in accordance with two converging principles: (I) the cognitive object is known/received by the cognitive faculty according to its nature («cognitum est in cognoscente secundum modum cognoscentis»/ «receptum est in recipiente, sed per modum recipientis») and (II) there must be a necessary proportion between the cognitive faculty and its object («obiectum debet proportionari potentiae»). According to the scheme exposed by Aquinas in the First Part of the Summa theologiae, as the human soul is the form of the body, its first cognitive object, the one it knows directly, is the immaterial essence («quidditas») of a material substance (e.g. the essence of table, not of this table). Consequently, human nature «orders» human beings to first grasp the universal forms abstracted by the intellect from the material substances; the cognition of anything immaterial (e.g. my soul, an angel, God), instead, can never be acquired directly by the human intellect.

This account, exposed in questions 84, 85 and 86 of the First Part, was the object of Duns Scotus' criticism. If, as Aquinas affirmed, the intellect's first and adequate object is the material substance, not even the blessed soul could have a perfect cognition of God in the afterlife. God would in fact exceed the intellect's nature and, more precisely, its object: for, «adequate», is the object which comprehends all that a cognitive power can know. In Ordinatio I d. 3 q. 3, Scotus makes his controversial claim on the univocity of being: he states that being is the intellect's adequate object, the one covering its whole cognitive extension and fitting its nature (the «natura potentiae»). Accordingly, the very nature of the human intellect is not to be linked to the material substances; they provide it with a direct cognition in the present state only («pro statu isto»), either 
owing to the divine punishment which followed the original sin, or to the natural connection between the soul's faculties. Scotus thus agrees with Aquinas that the first cognitum in the present state corresponds to the essence of the sensible substances. The combination of these two theses, both depending on the concept of nature, is thereafter familiar to the Scotists and, as we will see, to the Thomists as well.

In this paper, I will focus on how some early modern theologians from both schools of thought - Thomists and Scotists - dealt with the question of the intellect's first and adequate object and, more precisely, on how both sides reported Aquinas' view. In this paper, I will not fully address who was Aquinas' best Defensor, and who transmitted correctly his position. Rather, I will confine myself firstly, to trace down, by following the commentaries on Aquinas produced between the $15^{\text {th }}$ and $17^{\text {th }}$ centuries, the way his commentators effectively reported his view and secondly, to compare it with the criticisms later put to them by the Scotists. The commentators claimed that, without any doubts, their opponents, who were unable to reply to Scotus' objections, began, after the $15^{\text {th }}$ century to expound on the matter on the intellect's object just like their master did. In this paper, I have thus collected all the places mentioned by the Scotists, and thus brought to light this infinitesimal part in the story of how Aquinas was read. The implicit conclusion - perhaps even more radical than Macedo's - to which the Scotists of the $17^{\text {th }}$ century hint to, is that after Aquinas, not even his followers could follow his doctrine.

(I) To begin with, I will consider two different kinds of criticism made by the Scotists to Aquinas' commentators in the $17^{\text {th }}$ century. The most «dramatic» is indeed the one raised by the Portuguese Franciscan Francisco Macedo (1596-1681) in his Collationes (1671-1673). Macedo claims that Aquinas held three different and conflicting theses on the intellect's first object, thus bringing his commentators to echo his confusion. (II) The second form of criticism addressed to Aquinas was persistently diffused not only by Scotists such as Filippo Fabri, Bartolomeo Mastri and Bonaventura Belluto, Juan Merinero and Hugh McCaghwell. In the Decisiones philosophicae (1645-1646) by the Minim Jean Lalemandet (1591-1647), for instance, the author individuates a discrepancy among early modern Thomists, as well as the tendency, in their commentaries, to reproduce Scotus' position to approach the problem of the intellect's object. (III) In conclusion, I will examine the positions effectively expressed by the Thomists of the $17^{\text {th }}$ century mentioned by their opponents, the Scotists. 


\section{Francisco Macedo: Aquinas' account is inconsistent}

Francisco Macedo wrote the Collationes doctrinae s. Thomae et Scoti (1671-1673) - a text in which he compares the whole philosophy of Thomas Aquinas with that of John Duns Scotus' - whilst teaching in Padua ${ }^{1}$. Before becoming a Franciscan, he had been a Jesuit - he claims, in the introduction to the Collationes, to have visited Suárez's lectures in Coimbra - and a Discalced Augustinian, taking also part in the debate on Jansenism. In between, he broke his religious vows and participated in the civil war in Portugal. His compendium is at least as formidable as its author's biography, and a typical product of early modern Scholasticism. Such texts, in which Aquinas' philosophy is compared with Scotus', were largely widespread and mostly representative of the attempt at systematizing the oppositions between two worlds in conflict ${ }^{2}$. Here I will refer to the Collatio Quarta of the Collationes' first volume, where Macedo is concerned with the intellect's first and adequate object. According to his method, the author first presents the texts of the two philosophers and then gives his own reading, analysing the reasons why one position - the Scotist, as he «fights for Scotus» («pro Scoto pugno») - is better than the other. As I already mentioned, in the case of the intellect's first object, Macedo isolates three theses held by Aquinas in the First Part. Also, he claims that they are irreconcilable one with another.

In the First Part, Aquinas defined very precisely the range of every intellective power, assigning a different object to the intellects of God, the angel and human beings. Also, every cognitive power's nature has a connatural («connaturalis») and adequate cognitive object, due to its nature. Such cognitive powers are the senses, that act through a sense organ; the human intellect, that acts without a sense organ, but is tied to a material body; the angel, that acts through immaterial species only. This account is exposed in the questions 12 and 84 and is the first to be analysed by Macedo. He then mentions two other texts by Aquinas which open the ground for a discussion - as we can see, for example, in Cajetan's commentary. In Ia, q. 5, a. 2, Aquinas stated that being is the intellect's first known object («cognitum») and, in q. 3 a. 5, that «nothing is known before God» («nihil

\footnotetext{
${ }^{1}$ On Macedo's biography and production, see Troilo, E., «Franciscus a S. Augustino Macedo», in G. Bardi, Relazioni storiche fra l'Italia ed il Portogallo, Roma, Reale Accademia d'Italia, 1940, pp. 239-260; de Sousa Ribeiro, I., Francisco Macedo. Um filósofo escotista português e um paladino de la Restauraçao, Lisboa, Ordem da Universidade, 1951. See also Baù, A., «P. Francesco Macedone e P. Antonio Maria Bianchi docenti in filosofia all'Università di Padova», in C. Bérubé (ed.), Regnum hominis et Regnum Dei. Acta Quarti Congressus Scotistici Internationalis, Patavii, $24-29$ septembris 1976, 2 vols. Romae, Societas Internationalis Scotistica, 1978: II, pp. 337-343; Ceyssens, L., «François de Saint-Augustin de Macedo. Son attitude au début du Jansénisme», Archivum Franciscanum Historicum, 49 (1956), pp. 1-14; Tropia, A., «Scotus' Platonic Account of the Intellect in the Collationes by Francisco Macedo (1671-1673)», Historia Philosophica. An International Journal, 9 (2011), pp. 57-67.

${ }^{2}$ On the literature spreading from this academic context, see Schmutz, J., «Bellum Scholasticum. Thomisme et anti-thomisme dans les débats doctrinaux modernes», Revue Thomiste, 108 (2008), pp. 131-182.
} 
Deo prius»). These claims provide Macedo with the occasion to underline a certain confusion in Aquinas' text as well as in his commentators, like Cajetan:

S. Thomas in I. p. q. 5 a. 2 disputans, Utrum Bonum secundum rationem sit prius, quam ens? Sensit: Primum quod concipitur ab intellectu esse ens, atque adeo primum obiectum intellectum esse ens; imo et proprium, et adaequatum. Verba sunt perspicua in Corp. (...) Primo autem in conceptione intellectus cadit ens; quia secundum hoc unumquodque cognoscibile est, inquantum est in actu, ut dicitur 9. metaphysice: unde ens est proprium obiectum intellectus; et sic est primum intelligibile, sicut sonum est primum audibile. Quomodo haec sententia cohaereat cum proxima eiusdem D. Thomae asserente obiectum intellectus esse quidditatem rei materialis? ergo non video, nec vidit Caietanus, qui in suis Commentarijs ad eum locum exponens mentem D. Thomae circa istam prioritatem ait: rationem eius concludere, ens non solum esse prius secundum rationem bono, sed etiam omnibus alijs, et movet dubium de Deo (...). ${ }^{3}$

Macedo declares not to understand what is the intellect's first object according to Thomas: how, he says, can the primacy of being taken in the most general sense («ens in communi») be reconciled with that of material being, the «quidditas rei materialis»? This confusion, he says, has not been seen by Cajetan, who, instead, «raised a doubt about God» ${ }^{4}$ in his commentary to q. 3; such confusion is consequently presented like «new» by Macedo - a new incoherence in Aquinas' texts.

In the wake of these doubts, and not without a hint of polemics, the Franciscan concludes that, on the intellect's first object, Aquinas expressed not one, but three different conflicting theses and that no one, among the Thomists, has been able to solve the puzzle:

Itaque manent tres sententiae diversae de obiecto intellectus apud D. Thomam, nimirum esse Ens in communi p. I q. 5 a. 2. Esse Deum. P. I q. 3 art. I. Esse Ens materiale. q. 84 ar. 7. Nam dubito, quin Thomistae Angelici Theologi hanc difficultatem explicent, sed dum se ab illa explicant; meum iudicium esto. ${ }^{5}$

Macedo aims to show the inconsistency of his opponents, the Thomists. He mainly builds his argument to destroy Aquinas' thesis of the essence of the material thing («quidditas rei materialis»), emphasising its narrowness compared to Scotus' thesis on being. The difficulties he mentions, about Aquinas' three texts, somehow close the section on the intellect's first object like a witty «cauda»: not only Aquinas was confused on this matter, but so were his followers, like Cajetan, who have not been able to solve the difficulties in their master's text.

${ }^{3}$ Francisco Macedo, Collationes doctrinae sancti Thomae et Scoti cum differentiis inter utrumque textibus utriusque fidelita productis sententiis subtiliter examinatis, commentariis interpretum Cajetani, imprimis et Lychetis diligenter excursis, et aliarum pene omniam Scholarum, ..., 3 vols, Patavii, typis et sumptibus Petri Mariae Frambrotti, 1671 - 1673 ; I, Collatio IV, diff. 1, pp. 78-79.

${ }^{4} \mathrm{Cf}$. The aforementioned text, n. 2.

${ }^{5}$ Macedo, Collatio IV, diff. 1, p. 79. 
Macedo's text is indeed marked by partiality: for Aquinas' position is briefly considered in the wake of three texts, that, not thoroughly analysed by Macedo, present the same three puzzles. His position is radical and does not offer an insight on the current way Thomas Aquinas was read in his day; it constitutes an extreme unicum in the panorama of Aquinas readings by the $17^{\text {th }}$ century Scotists. To understand them, I will take a step back and start off with examining Cajetan's interpretation, poorly estimated by Macedo but, in my opinion, the most adherent defence of Thomas Aquinas.

\subsection{Cajetan: the canonical reading in defence of Aquinas' account}

Macedo is correct when he blames Cajetan for not having noticed the ambiguity between the primacies of being in general and being in particular («ens materialis»), inasmuch as for Cajetan there is no ambiguity in Aquinas' text. In his commentary on the First Part (1507), Cajetan does not analyse how the intellect grasps ens in general, keeping the metaphysical problems (as well as an important comparison with Scotus) for the first question of his reading on De ente et essentia. Brought by Scotus to question whether ens in general is the intellect's first object, he rejects it following his master's path. ${ }^{6}$

In his reading of questions 12 and 84, Cajetan puts at the centre of his reflection the concept of nature and follows Aquinas by (re)proposing a theory that we may call «one mind-one proper object». In a very effective synthesis, he states that the measure of what a cognitive power can know is given by its own nature («mensura naturalis cognitionis est ipsa cognoscentis natura»). ${ }^{7}$ That is why the human intellect cannot know God directly and by its own means (q. 12, a. 4). As the form of a material body, it is somehow «confined $»^{8}$ to the knowledge of the external sensitive world (q. 84 a. 7). Since the human intellect is the least noble among the intellective powers (inferior to the separate soul, the angels and God), it needs by its own nature to cooperate with the sensible powers and the sensible species to acquire knowledge of both universals and singulars.

Cajetan strongly defends Aquinas from Scotus' criticisms. On the intellect's first object, moreover, Scotus is the only opponent to Aquinas he mentions. It is thinking of the philosopher's theological objection to his master that, in his commentary to q. 84 a. 7 , he claims that the essence of the material thing is not the intellect's first and adequate object in general («absolute»), nor the blessed soul's («intellectus coniunctus

${ }^{6}$ Cf. Cajetan in Ia, q. 84, a. 7, in V, p. 327, n. XI.

${ }^{7}$ Cf. Cajetan in Ia q. 12 a. 4 , in IV, p. 122.

${ }^{8}$ I am referring to Macedo's words: cf. Macedo, Collatio IV, diff. 1, p. 76: «(...) ex his sensisse D. Thomam obiectum primum, et adaequatum esse quidditatem rei materialis, Primum, quia intellectus immersus in materiam accipit species a sensibus, et immediate cognoscit materialia; adaequatum, quia etsi cognoscat immaterialia, ea non nisi abstrahendo a materia in qua versatur, agnoscit; unde stringitur, et clauditur in materiae carceribus.» 
corpori glorioso»). Aquinas referred this thesis to the intellective power united to the body only:

Prima conclusio: intellectus coniunctus corpori passibili non potest intelligere nisi convertendo se ad phantasmata. Ubi nota duas limitationes. Prima, quod non est hic sermo de intellectu nostro absolute, aut secundum statum separationis a corpore; sed de eo ut coniunctus est corpori. Secunda est, quod non loquimur de eo ut coniunctus corpori glorioso, ut in resurrectione erit, sed corpori passibili. ${ }^{9}$

Scotus' objection concerning the blessed soul is thus neutralized by Cajetan. The texts he criticized focus on the object that the human intellect can grasp naturally, without the help of other powers («ex natura potentiae secundum proprias vires» ${ }^{10}$ ), and «quidditative», grasping the essence, the «quid est», of a substance. According to Cajetan, such an object is known by the intellect «intensive ex natura potentiae», in opposition to «extensive» and in general ${ }^{11}$. Differently from Scotus, Cajetan then affirms that, through grace only, the intellective power extends its usual cognitive range, and can thus be elevated to the direct knowledge - «visio» - of God:

Quoniam, ut iam patet, de obiecto non quomodocumque, sed quidditative cognoscibili naturaliter, est sermo: (...) Cum quo tamen stat, quod potest per gratiam elevari ad quidditative cognoscendum etiam Deum. Non enim inconvenit potentiam elevari ad cognoscendum aliquid quidditative, quod est extra obiectum quidditative cognoscibile a se naturaliter. (...) Iam enim dictum est quod hic est sermo de obiecto adaequato intensive ex natura potentiae secundum proprias vires: et non de obiecto adaequato extensive, extra quod nullus habitus adducere quomodolibet potest potentia. ${ }^{12}$

Hence, in the questions criticized by Scotus, Cajetan stresses that Aquinas just described the human intellect's capacity according to its nature, without the intervention of grace. As we have seen, he uses the pair «intensive - extensive» to qualify knowledge according to the modality of acquisition: either directly, namely acquired by the intellect by its own means («intensive»), or indirectly, namely acquired by way of analogy with the first one («extensive»). It is the case of being in general and of spiritual substances, known indirectly through the material substance («in ordine ad quidditatem sensibilem») and through their traces («conditione vestitum»). ${ }^{13}$ Cajetan then solves any possible ambiguity stating that, in the human intellect's case, the

${ }^{9}$ Cajetan in Ia q. 84 a. 7, p. 326.

${ }^{10}$ See, i.e., Cajetan in Ia q. 12 a. 4 , in IV, p. 123.

${ }^{11} \mathrm{Cf}$. Cajetan in Ia q. 12 a. 4, V, p. 122: «(...) obiecta quae assignantur potentiis, non sunt obiecta adaequata extensive, sed sunt obiecta adaequata intensive naturaliter: quia supra illa non potest naturaliter potentia quidditative penetrare.»

${ }^{12}$ Cajetan, in Ia, q. 12, a. 4, t. IV, VI, p. 123.

${ }^{13}$ Cajetan, in Ia, q. 84, a. 7, XI, p. 327: «(...) nihil potest intellectus noster naturaliter intelligere nisi in ordine ad quidditatem sensibilem. Quidquid enim de Deo aut angelis naturaliter attingimus, causalitatis aut excellentiae aut negationis respectu sensibilium, conditione vestitum cognoscitur, ut experimur.» 
essence of the material being is the sole possible object, both «intensive» and «extensive». What brings the intellective power to acquire cognition («ratio motiva») and this cognition's achievement («ratio terminativa») then coincide:

Quidditatem enim rei sensibilis obiectum non quodcumque, sed naturaliter proportionatum intensive ponimus intellectus nostri: quia nihil potest naturaliter intellectus cognoscere quidditative nisi naturas sensibilium. Et pro statu isto non solum est intensive, sed extensive obiectum intellectus: quia nihil potest intellectus noster naturaliter intelligere nisi in ordine ad quidditatem sensibilem. (...) Unde et ipse Scotus, a veritate coactus, dicit quod quidditas sensibilis est intellectus nostri pro statu isto obiectum in ratione motivi; quamvis, minus philosophice loquens, neget in ratione terminativi, ut patet ex dictis. ${ }^{14}$

The reflection on the primacy of «ens» in general, stimulated in Cajetan by Scotus' objections, is rejected following the Thomist path, thus reinforcing the difference between what the human intellect can know immediately («intensive») and in general («extensive»). «Being in general» and spiritual substances are known by the human intellect only through the material substances. In Cajetan's commentary there is no place for any ambiguity: he sharply distinguishes Aquinas' account from what he calls Scotus' (bad) «mixture» («mixture»). ${ }^{15}$

To sum up: in his commentary, Cajetan defends Aquinas from Scotus' accusation by underlining that the thesis on the essence of material being as the intellect's first cognitum concerns the human intellect only. Focusing on the concept of nature, in the wake of Aquinas Cajetan specifies that the union between the intellective power and the body produces a certain kind of cognition, defined by the necessity of the sensible species. This union, contrarily to what Scotus stated, is natural and does not result from a divine punishment ${ }^{16}$. The thesis on «ens» taken in its most general sense is rejected

${ }^{14}$ Cajetan, in Ia, q 84, a. 7, XI, p. 327.

${ }^{15}$ Cajetan in Ia, q. 12 a. 4, IV, VI, p. 123: «Propositiones autem ex quibus littera procedit, etsi non sunt syllogisticae formaliter, sunt tamen virtualiter; ut superius eas ordinavimus valde facile, absque tanta mixtura quantam fecit Scotus.»

${ }^{16}$ On the divine punishment modifying the intellective power's capacity in Scotus, see the famous passage of Ordinatio, I, d. 3, q. 3, Wadding, V.1, p. 466: «(...) pro statu isto ei [intellecti] adaequatur in ratione motivi, quiditas rei sensibilis. Et ideo pro statu isto non naturaliter intelliget alia, quae non continentur sub illo primo motivo. Si quaeritur quare est ratio istius status: Respondeo, status non videtur esse nisi stabilis permanentia legibus divinae sapientiae firmata. Stabilitum est autem illis legibus sapientiae, quod intellectus noster non intelligat pro statu isto, nisi illa, quorum species relucent in phantasmate, et hoc sive propter poenam originalis peccati, sive propter naturalem concordiam animae in operando (...).» See also Cajetan replies in his commentary to Ia q. 84, a 7, n. XVI, p. 327-328: «Scotus enim in Primo, d. III, q. III, et in Quarto, dist. XLV, qu. II, consentiens conclusioni principali, scilicet quod nihil sine phantasmate intelligimus, dissentit in medio. Vult enim quod hoc non insit intellectui nostro ex se absolute, quia sic anima separata non intelligeret; nec ex hoc quod coniunctus est corpori, quia sic anima in corpore glorioso egeret phantasmate. (...) XVII. Ad obiecta vero in oppositum dicitur quod hoc est naturale animae nostrae 
by Cajetan, because in the present state (being united to a material body), the human intellect needs the sensible species for acquiring knowledge: they furnish it with the departure point to obtain cognition and, at the same time, as the horizon containing every possible cognitive object. «Ratio motiva» and «ratio terminativa», in Cajetan's account of cognition, coincide.

Thus, Cajetan's defence is based on the substantial agreement with Aquinas' thesis - that in the present state, every human cognition is filtered via the senses and is indirect, when it extends to the knowledge of what is immaterial. The rejection of Scotus passes via the fact that his opinion is held as wrong, insofar it does not take into account the nature of the cognizer. Cajetan does not see any inconsistency in Aquinas, as Macedo will do, and carefully comments on the text of the Summa.

\section{3. "Thomistae discrepare inter se»: another canonical reading of Aquinas}

Cajetan's commentary is perhaps the most faithful reading of Aquinas' account of cognition exposed in the Pars prima. As we will see, after him, not every commentator of the Summa will comment on Aquinas with the same adherence. This is, at least, what a group of early modern theologians observed in such works: on the intellect's first object, the Scotists of the seventeenth century, as well as the Minim Jean Lalemandet, noticed a certain tendency to follow Scotus among the Thomists. We find this sentence, unmodified, in many and different texts. Let us start off with Lalemandet's.

In his Decisiones philosophicae (Prague, 1645-1646), later reprinted as Cursus philosophicus (Lyon, 1656), the French Minim Lalemandet synthetized and confronted the positions expressed by the three viae - the Thomist, the Scotist and the nominalist one. ${ }^{17}$ Lalemandet's text works effectively like a philosophical handbook: on the intellect's first object, after mentioning Aquinas' and the Scotist thesis, the author moves on to explain the lexicon usually employed for the first cognitum, as well as the difference between the ratio motiva and the ratio terminativa.$^{18}$ Correctly, he ascribes to

ex modo essendi, scilicet in coniunctione ad corpus: unde conveniebat etiam in statu innocentiae. Et cum infertur, Ergo convenit etiam animae in corpore glorioso, negatur consequentia: quoniam de statibus pure naturalibus loquimur, et non de miraculosis. (...) Ratio vero ex peccato originali non est naturalis: hoc autem est naturalis, ut mori, etc.»

${ }^{17}$ Jean Lalemandet, Cursus philosophicus complectens, lateque discutiens controversias omnes a Logicis, Physicis, Metaphysicisque agitari solitas, praesertim quae Thomisticae, Scoticae, et Nominalium Scholis sudorem cient. Lugduni, sumpt. Laurentii Anisson, 1656 (the previous version of the Cursus, the Decisiones philosophicae, and the Cursus philosophicus are both accessible on googlebooks). On the author, see «Lalemandet, Jean», in J. Schmutz, Scholasticon, URL = http://www.scholasticon.fr/. On Lalemandet's Cursus, cf. Edwards, M., «Body, soul and anatomy in late Aristotelian psychology», in G. Manning (ed.), Matter and Form in Early Modern Science and Philosophy, Leiden, Brill, 2012, pp. 33-76.

${ }_{18}$ Cf. Lalemandet, Cursus philosophicus, disp. XVI, part. V, p. 618: «Communiter dividunt obiectum intellectus Animastici in motivum, et in terminativum: motivum vocant omne ens sensibile ab intellectu perceptibile, quod ideo vocant motivum; quia sensibilia per suas species 
Aquinas the thesis that the human intellect's first cognitum is the ens materialis, and to Scotus the claim that ens taken in its most general sense is the intellect's adequate object. On Aquinas' position, though, Lalemandet remarks that the Thomists had different opinions («thomistas discrepare inter se»). Some of them, like the Italian Dominican Crisostomo Javelli (1470-1534), ${ }^{19}$ held that the essence of material being is the human intellect's first object in the present state only, reserving to «being» the role of first cognitum in general, as the adequate object of the intellective power:

Nota specialiter pro opinione D. Thomae ipsos thomistas discrepare inter se; nam Iavellus 3 de anima qu. de obiecto intellectus possibilis dicit D. Thomam ponentem pro obiecto intellectus ens sensibile loqui de obiecto intellectus pro hoc statu: Caietani mens super hoc non est aperta, ut recte notavit Faventinus ${ }^{20}$. Petrus Niger q. I Clypei vult D. Thomam, et Scotum concordare in assignando obiecto intellectus, et discordare solum in eo, quod D. Thomas nolit ens esse univocum, Scotus vero id asserat, sed haec controversia metaphysica omnino est, et ample a nobis determinata in metaphysica: etc. ${ }^{21}$

Lalemandet's text provides us with an interesting doxography: to the famous Javelli, he associates the German Dominican Petrus Schwarz, author of the Clypeus Thomistarum (1481) ${ }^{22}$. It is rather uncommon to find Schwarz's rare work quoted in early scholastic texts; Schwarz is nowadays mostly studied for his involvement in the conversion of the Jews as a Hebraist and a preacher ${ }^{23}$. Lalemandet had perhaps the intention of furnishing his readers with the most accurate historical reconstruction of the Thomists' positions. Be this as it may, he ascribes to Schwarz the thesis of a

movent, et excitant intellectum: terminativum illud esse dicunt, quod non movet intellectum per se, percipitur tamen ab eo, quales sunt omnes res spiritales.»

${ }^{19}$ For Javelli, see Tavuzzi, M., «Chrysostomus Iavelli OP (c. 1470-1538). A Biobibliographical Essay: Part I, Biography», Angelicum, 67 (1990), pp. 457-482; Id., «Chrysostomus Iavelli OP (c. 14701538). A Biobibliographical Essay: Part II, Bibliography», Angelicum, 68 (1991), pp. 109-121.

${ }^{20}$ «Faventinus» is the Italian Scotist Filippo Fabri, whose text we shall examine. I do not agree with this remark by Lalemandet on Fabri's judgement on Cajetan («Caietani mens super hoc non est aperta, ut recte notavit Faventinus»): on the contrary, Cajetan's commentary is accurately discussed by Fabri, who considers the Cardinal as Aquinas' best interprete - and thus deserves his whole attention.

${ }^{21}$ J. Lalemandet, Cursus philosophicus, disp. XVI, part. V, p. 618.

${ }^{22}$ Petrus Niger, Clypeus thomistarum in quoscumque aduersos: per venerabilem virum fratrem Petrum Nigri ex ordine praedicatorum, Venetiis, per magistrum Raynaldum de Nouimagio theothonicum, anno Domini 1481. The edition of Venice, 1504, has been digitalized by the Bayerische StaatsBibliothek and is now accessible on the website Deutsche Digital Bibliothek (DDB): /www.deutsche-digitalebibliothek.de.

${ }^{23}$ See, for example, the recent work by Diemling, M., «Petrus Nigri (Petrus Schwarz). FifteenthCentury Polemicist, Preacher and Hebraist», in E.H. Füllenbach, and G. Miletto (eds), Dominikaner und Juden/ Dominicans and Jews, Berlin, De Gruyter 2015, pp. 299-317. See also Vollkmann, B.V., «Nigri, (Schwarz) Petrus», in Die deutsche Literatur des Mitteralters. Verfasserlexicon, 6 vol., Berlin - New York, De Gruyter, 1987, pp. 1008-1013. 
supposed agreement between Aquinas and Scotus concerning the intellect's first object, with the unique difference that "Aquinas did not hold the univocity of being». ${ }^{24}$

Before - and after - Lalemandet, many Scotist texts refer to a «discrepantia» among the Thomists concerning the intellect's first object. As the texts we are going to mention are all very similar, I will focus only on one of them, Filippo Fabri's Philosophia naturalis (1602), ${ }^{25}$ one of the first to formalize the Thomists' positions and whose littera can be found, more or less unchanged, in many Scotists of his day. In his work, which is a summa of Scotus' philosophy divided into «theorems», Fabri presented the division among the Thomists in terms that Lalemandet will subscribe to; nevertheless, his analysis is more in-depth than the French Minim's. Just like Lalemandet does, Fabri observed that, concerning the intellect's first object, Aquinas' supporters did not convey the same interpretation of their master, and he also individuated in Javelli's reading an alternative to Cajetan's. In his commentary On the Soul (1552), Javelli had actually attributed to Aquinas two thesis concerning the intellect's first object, distinguishing between the present state and the primum cognitum in general: «ex natura potentiae/absolute». Had Aquinas stated this, says Fabri, he and Scotus would have held the same position. However, such a reading of the Doctor Angelicus' text is false («sed re vera haec non est D. Thomae»); there is no agreement between the two philosophers concerning this matter:

Iavellus 3 libro de anima, quaestione de obiecto intellectus possibilis, aperte ait, Scotum, et alios decipi, quia mentem D. Thomae non perceperunt: unde ait D. Thomam asserere quoque obiectum adaequatum intellectus ex natura potentiae, esse ens, et hoc probat in questione prima de obiecto intellectus; quando autem D. Thomas dixit quidditatem rei materialis esse obiectum intellectus, loquitur de obiecto adaequatum pro hoc statu, sive de obiecto motivo intellectus pro hoc statu: manifestum est autem quod hoc est quidditas rei materialis, et ideo frustra arguunt Scotus, et alij contra D. Thomam. Si haec sit mens

\footnotetext{
${ }^{24}$ To be true, in his Clypeus Schwarz held that material being plays the role of «ratio motiva» and being in general that of «ratio terminativa» in the human cognitive process: cf. Schwarz, Clypeus Thomistarum, q. I, fol. 3: «Nos autem ponimus obiectum intellectus nostri ut coniunctus est quidditatem rei materialis, idest in quantum intellectus habet talem modum essendi (...) Obiectum primum per se intelligibile nostri intellectus est ens inquantum ens hoc intelligere in ratione terminativi. Haec opinionem tenens Avicenna in primo sue metaphysice, et sanctus Thomas parte prima quaestione quinta; (...) dicendum quod quidditas rei materialis est obiectum intellectus nostri in ratione motivi solum: non autem in ratione terminativi.»

${ }^{25}$ Filippo Fabri, Philosophia naturalis Jo. Duns Scoti, ex quatuor libris sententiarum et quodlibetis collecta, in theoremata distributa et contra adversarios... defensionibus illustrata... Cui praemissa sunt viginti theoremata, praecipuas difficultates logicas complectentia, et in cujus fine additus est tractatus brevis, facilis, et necessarius in formalitates Scoti, auctore fratre Philippo Fabro, Venetiis, apud J. Bertonum, 1602. On this scholastic (1564-1630), see J. Schmutz's page in the already mentioned website «Scholasticon».
} 
D. Thomae patet quod Scotus, et ipse D. Thomas concordes sunt; sed re vera haec non est

D. Thomae, ut patet inspicienti opinionem eius, quam retulimus. ${ }^{26}$

According to Fabri, Javelli's interpretation is wrong, because Aquinas did not distinguish between an adequate object «pro statu isto» and "absolute». Moreover, the primacy of the material being's essence is always connatural to the human intellective power, namely the intellect united to a body, and in any state («in quocumque statu», i.e., in the state of innocence): what determines it, is the relation of the soul with the body as its form. The only «upgrade» the human intellect can aspire to, together with a more complete knowledge, is that provided by the intervention of grace ("per lumen gloriae»):

Clarum est enim quod loquitur D. Thomas de obiecto adaequato intellectus ex natura potentiae; unde assignans rationem, propter quam quidditas rei materialis est obiectum intellectus, sumpsit fundamentum a natura potentiarum cognitivarum, non a statu, et dixit animam nostram ex eo quod est forma materiae, non posse cognoscere nisi ea, quae sunt materialia; modo quod anima sit forma materiae, competit ei ex propria natura, et per hoc distinguitur ab intelligentijs, ergo cum dixit obiectum intellectus esse quidditatem rei materialis, locutus est de intellectu secundum naturam potentiae, non pro hoc statu tantum, immo loquendo de cognitione essentiae Divinae, quam secundum Theologos habebit anima nostra in alio statu, ait quod illam non habebit ex virtute potentiae propriae intellectus, sed per lumen gloriae, et supernaturaliter, quia ex propria virtute solum obiecta naturalia intelligere potest, ergo loquitur ex natura potentiae in quocunque statu. ${ }^{27}$

According to Fabri, Javelli's reading differs from Aquinas' account of cognition. Javelli also commented on the First Part, but his reading touches the first thirteen questions only, and is centred on the Trinity and God's attributes. ${ }^{28}$ We can thus observe that Javelli's «alternative» reading of Aquinas, which approaches his account of

${ }^{26}$ Fabri, Philosophia naturalis, Theorema 86, cap. 3, p. 577. Fabri faithfully reports Javelli's text: cf. Crisostomo Javelli, Super tres libros Aristotelis de anima quaestiones subtilissimae, in quibus carissime resolvuntur dubia Aristotelis, et Commentatoris, eaque ut plurimum decisa habentur iuxta Thomisticum dogma, Venetiis, apud Hieronymum Scotum, 1552, lib. III, q. 1, p. 179: «In hac quaestione adverte, quod intendimus loqui de obiecto intellectus nostri, non absolutae considerari, sic enim de eo locuti sumus in quaest. praecedenti sed de obiecto eius, ut coniunctus est, sive pro statu praesentis vitae. In hoc igitur proposito adverte, quod plures ut Scot. et Aur. et Aver. impugnant B. Th. potius verbis quam sensu, eo quod non habuerunt, nec intellexerunt mentem B. Th. arbitrantur enim quod B. Th. teneat quidditatem materialem esse primum et formale et adaequatum obiectum intellectus nostri coniuncti, quod tamen est falsum, nec ista fuit mens D. Thom.» (The quoted edition is accessible on googlebooks).

${ }^{27}$ Fabri, Philosophia naturalis, Theorema 86, cap. 3, p. 577.

${ }^{28}$ Cf. Crisostomo Javelli, Expositio praeclarissima eximii Magistri Chrysostomi Javelli... in primum tractatum primce partis angelici doctoris D. Thomae Aquinatis... in Divi Thomae Aquinatis,... Totius theologice summa, in tres partes digesta, \& ad Romanum exemplar collata. Cum commentariis R. D. D. Thomae de Vio Cajetani... t. I: I. Prima pars, cui addita sunt commentaria R. F. Chrysostomi Javelli ad librorum prohibitorum indicem... Lugduni, apud S. Michaelem, 1588. 
cognition to Scotus', is vehiculated by a commentary On the Soul, and not by his commentary on the First Part.

As for Cajetan, Fabri remarks that his defence of Aquinas differs from Javelli's ${ }^{29} \mathrm{His}$ commentary is more adherent to the littera and, as it presents a battery of anti-Scotist arguments, it is deeply analysed (and refuted) by the Scotist. Here I will highlight mostly three points of Fabri's digest of Cajetan's commentary. (1) According to the Scotist, Cajetan correctly reads Aquinas' text and does not furnish another version of his account of cognition, like Javelli did; (2) concerning the two theses on the primacy of being in general and material being, in the wake of Aquinas, Cajetan established that the essence of material being is the human intellect's first object «intensive», acquired by its own means and naturally (ex natura potentiae), while being in general, is the intellect's first object «extensive», and the human intellect can grasp it after the intervention of grace only:

Ex his verbis apparet quod secundum eum obiectum adaequatum intellectui ex natura potentiae cognoscibile quidditative ab ipso, est eiusdem ordinis, et generis, cuius est anima, neque aliud ens altioris generis, vel ordinis potest intelligi, et percipi ab anima quidditative ex natura animae; anima autem est quidditas materialis, quia est forma materiae, et sic obiectum eius materialiter, et quidditative cognitum, est quidditas rei materialis, quia est eiusdem ordinis cum anima. Si vero loquamur secundum gratiam Dei, potest quidem etiam intellectus noster intelligere, et hoc est quod dicit quidditatem rei materialis esse obiectum intellectus adaequatum intensive solum, non extensive, quia obiectum intellectus extensive est omne ens, nam anima ex propria natura non potest intendere plusquam in quidditatem rei materialis, sed ex gratia potest extendere se ad cognitionem cuiusvis entis, etiam extra quidditatem rei materialis (...). ${ }^{30}$

(3) Fabri claims that, at the core of Cajetan's reading, there is the necessity to establish that the object and the cognitive power share the same "order and genre»: there is a convenientia generica between the soul and its cognitive object. ${ }^{31}$

${ }^{29}$ Fabri, Philosophia naturalis, Theorema 86, cap. 3, p. 577: «Aliter igitur pro D. Thoma quam Iavellus, et concedit mentem D. Thomae esse quod quidditas rei materialis est obiectum adaequatum intellectus nostri ex natura potentiae, ut patet ex ijs, quae dicit in corpore illius expositionis, et respondendo ad argumenta, et maxime ad quartum ubi habet hac verba: 'Concedo quod intellectus ex natura non potest quidditative cognoscere altius quidquam sit natura animae nostrae; cum quo tamen stat quod potest per gratiam elevari ad cognoscendum quidditative, quod est extra obiectum quidditative cognoscibile, a se naturaliter'.»

${ }^{30}$ Fabri, Philosophia naturalis, Theorema 86, cap. 3, p. 377-378.

${ }^{31}$ Cf. Fabri, Philosophia naturalis, Theorema 86, cap. 3, p. 578: «[secundum Caietanum] debet esse proportio inter cognitum, et potentiam cognoscitivam, sic quod cognitio quidditativa obiecti non debet excedere modum cognoscendi potentiae, et insuper debent habere eumdem modum essendi, non quidem specifice, sed generice, ita quod debent esse eiusdem ordinis, et generis, non autem cognitum debet esse altioris ordinis; (...).» 
As I already said, Fabri's remark on the differences among the Thomists is presented, more or less in the same words, in many Scotist texts. The most influential is certainly the commentary to Scotus' De anima by the Irish Franciscan Hugh McCaghwell, published together with the famous and authoritative Wadding edition of Scotus' works (Lyon, 1633). In the explanatory notes following the chapter on the intellect's first object, McCaghwell discusses the Thomists' positions and, in particular, Cajetan's and Javelli's. Just like Fabri did, he claims that Javelli and his followers were wrong in explaining their master's thought («verum glossa haec non videtur subsistere»). ${ }^{32}$ Again, Cajetan's reading is considered as the most adherent to Aquinas and, consequently, the sole Thomist reading to be the object of McCaghwell's attention (and refutation). ${ }^{33}$ The same doxography, that presents on the one hand, Aquinas' most faithful ones - Capreolus and Cajetan mostly - and, on the other, Javelli and the modern Thomists (the «recentiores»), can be found also in the important scholastic commentary on Scotus' De anima by Bartolomeo Mastri and Bonaventura Belluto (Venice, 1643)..$^{34}$ They recognize too that the «Thomistae recentiores» follow Javelli's

${ }^{32}$ Cf. Hugh McCaghwell, Annotationes in De anima, q. 19, conclusio I, in Wadding II, p. 559: «Thomistae in explicatione Divi Thomae in hac parte, non conveniunt. Iavell. 3 de Anima 9, de obiecto intellectus possibilis, dicit quod loquitur D. Thomas de obiecto intellectus humani pro hoc statu; dum ait esse quidditatem rei materialis, quodque secundum naturam potentiae, ponit ens esse eius obiectum: quod si verum esset, Scotus, et ille conveniret. Verum glossa haec non videtur subsistere.»

${ }^{33}$ Cf. McCaghwell, Annotationes in De anima, q. 19, pp. 559-560.

${ }^{34}$ As for Mastri and Belluto, we cite the edition of 1678: B. Mastri, B. Belluto, Philosophiae ad mentem Scoti cursus integer... tomus tertius continens disputationes ad mentem Scoti in Aristotelis Stagiritae De anima, de generatione et corruptione, de coelo et de metheoris, Venetiis, apud Nicolaum Pezzana, 1678, Disputatio VI, q. VI, p. 203 \$160: «Quaesitu hoc agitari potest de intellectu nostro, tum pro statu isto, in quo vires habet suas quodammodo ligatas sensibus, tum ex natura potentiae, secundum quam considerationem a sensibus praescindit, ac veluti quocunque impedimento solutus consideratur, et eius adaequatum obiectum in utraque consideratione hic inquirimus, et per adaequatum obiectum intelligimus illud, quod non excedit ipsam potentiam, neque exceditur ab illa, nihilque intra ambitum illius obiecti continentur, quod ad illam potentiam non pertineat, nec aliquid pertineat ad illa potentiam, quod sub illo obiecto non contineatur, ut dictum est in logica. Thomistae in hac re non satis inter se conveniunt de mente D. Thom. cum enim p. p. q. 12 art. 4 et q. 84 art 7 et q. 87 art. 3 statuisset quidditatem rei materialis nostri intellectus obiectum, id aliqui absolute intellexerunt de obiecto intellectus nostri ex natura potentiae, ita Caietanus dictis in locis, et Capreolus p. 2 q. 1 et alij quamplures, in quo sensu opinio D. Thom. solide reijcitur a Doctore p. d. 3 q. 3. Alij vero volunt D. Thom. dum ait quidditatem rei materialis esse obiectum adequatum intellectus humani coniuncti, loqui de obiecto intellectus pro hoc statu, non ex natura potentiae, sic enim obiectum eius adaequatum est ens in tota sua latitudine, ita Iavell. 3. de anima q. de obiecto intellectus, Bannes p. p. 84, a 7, Complutenses disp. 16 de anima q. p. et 2 alii recentiores communiter, in quo sensu intellecta D. Thom. opinio parum, vel nihil distat a sententia Scoti, quam espressi p d 3 q. 3 et quolib. 14 art 2 et in de anima q. 19, 20, et 21 et bene adnotarunt Faber theor. 85 et Cavellus in q. 19 cit de anima annot. P. qui tamen ibidem demonstrant D. Thom de obiecto adaequato intellectus nostri ex natura potentiae locutum esse, cum ait obiectum adaequatum eius esse quidditatem rei materialis, et in hoc sensu quoque eum citant Regentes Parisienses 3 de anima q. 2 ad q. p. collater.» 
reading of Aquinas, which «does not differ much, or at all, from Scotus' text» ${ }^{35}$. Be this as it may, in their commentary, Mastri and Belluto also claim that this Scotist reading of Aquinas is false, like Fabri and McCaghwell had already pointed out. ${ }^{36}$ Juan Merinero López's commentary on Scotus' De anima (Madrid, 1659) echoes these readings. ${ }^{37}$ The aforementioned texts present the integration, by certain Thomists, of «Scotus' two theses» on the intellect's first object, «pro statu isto» and «ex natura potentiae», and the divergence with Cajetan. I might only want to add a word about Merinero's commentary On the Soul, as, after presenting the Thomists' positions, he claims that Aquinas effectively supported the two theses. Perhaps provocatively (as he does not seem to care about establishing Aquinas' real position) ${ }^{38}$, Merinero quotes a passage from Prima, q. 79, where being is said to constitute the intellect's whole cognitive range:

Porro secundum D. Thomam intellectum nostrum ex natura sua se extendere ad omne ens, et consequenter ens in tota sua latitudine esse obiectum adaequatum intellectus nostri, patet ex verbi eius; nam I. part. quaest. 79 art. 7 sic ait, Intellectus recipit suum obiectum secundum communem rationem entis, eo quod intellectus possibilis est, quod est omnia fieri. Unde secundum nullam differentiam entium diversificatur intellectus possibilis; quid clarius? ${ }^{39}$

${ }^{35}$ See the previous note: «(...) Alii Recentiores communiter, in quo sensu intellecta D. Thom. opinio parum, vel nihil distat a sententia Scoti, etc.»

${ }^{36} \mathrm{Cf}$. the previous section on Fabri as well as n. 33.

${ }^{37}$ Juan Merinero (1583 -1663) is a Spanish Scotist and an important figure within the Franciscan Order in the $17^{\text {th }}$ century. Professor of theology, he was Provincial and then General of the whole Franciscan Order (1639-1645). Cf. Juan Merinero, Commentarii in tres libros Aristotelis de anima, iuxta subtilis doctoris Ioannis Duns Scoti mentem, una cum disputationibus et quaestionibus, hoc tempore agitari solitis. Matriti aud Matthaeum Fernandez Typographum Regium, anno 1659: De anima, liber III, disp. IV , q. 2, §10, p. 373: «Non me latet, inter discipulos D. Th. dissidium esse in explicanda mente Angelici Doctoris; nam Caietanus in articulum 4 q. 12 primae partis D. Thomae, etsi ita lubricus sit, ut vix capias eius mentem; tamen ad 4 et in corpore expositionis admittit secundum D. Thomam, quidditatem rei materialis esse obiectum intellectus humani, non qualecumque, sed ex natura potentiae, et consequenter adaequatum, et idem sentiunt Capreolus loco supra citato, et aliqui alij Thomistae; imo Scotus noster in hoc sensu intellexit sententiam D. Thomae, et quia eodem modo loquitur de intellectu humano, assignando ei obiectum, ac loquitur de sensu, et de intellectu Angelico, sed de his loquitur I. parte, quaest. 85 a. 1 secundum naturam suam; ergo et de intellectu humano. Item ratio D. Thomae de proportione in modo essendi recquisita inter potentiam cognoscitivam, et obiectum eius, qua usus est ad probandum, obiectum intellectus nostri esse quidditatem rei materialis, si quid probaret, probaret utique, quidditatem rei materialis esse obiectum intellectus nostri, non solum pro hoc statu, sed etiam ex natura potentiae, seu adaequatum; quia anima nostra ex natura sua non solum pro hoc statu, sed etiam pro futuro est forma corporis, petens esse in materia.»

${ }^{38} \mathrm{Cf}$. Merinero, De anima, lib. III, disp. IV, q. II, §12, p. 374: «Sed quidquid sit de ista controversia, quae, ut dixi, versatur inter Discipulos D. Thomae in explicando mentem eius; tenendum est cum Scoto nostro in I. dist. 3 q. 3 num 8 et in 4. dist. 49 quaest. 11 et de anima quaest. 10 obiectum adaequatum intellectus nostri esse ens reale in tota sua latitudine sumptum. Etc.»

${ }^{39}$ Merinero, De anima, lib. III, disp. IV, q. II, §11, p. 374. 
From this rapid presentation, there are some considerations to make. On the problem of the intellect's first object, in the seventeenth century some of the most influential Scotist theologians, as well as the eclectic Minim Lalemandet, started off with presenting a division among the Thomists in their doxographies: on the one hand, Aquinas' most faithful party, made by Capreolus (whose commentary on the Sentences is usually referred to without a proper discussion, differently from Cajetan's), Cajetan and others, holding that the human first and adequate object «in every state» is the essence of material being; on the other one, Javelli - «that the contemporaries use to follow $»^{40}$ - and the «recentiores», holding two theses: one for the present state and the other, «in general». This double presentation aimed to weaken the opponents' party: as we have seen, rather explicitly, Macedo's purpose was to highlight the inconsistency of Aquinas' thesis, echoed by his school. As for the other Scotists (as well as for Lalemandet) I have mentioned, they put the accent, mostly, on the fact that the proximity between Aquinas' and Scotus' thesis on the intellect's first object, supported by the modern Thomists, was false or, like Merinero highlights, at least problematic. The last observation I can make is that, in these commentaries, the metaphysical debates are left aside and there is no mention of the univocity of being.

\section{4. (Some) Early Modern Thomists: Báñez, Zumel, the Complutenses}

In this third and last section, I will analyze the commentaries on the Prima Pars by three Thomists contemporaries to the texts mentioned above. The first one is the commentary by the «Thomista rigidus» Domingo Báñez (1528-1604), printed in 1588, ${ }^{41}$ and included by the Scotists in their list of the modern Thomists following Scotus. ${ }^{42}$ Báñez's commentary is very instructive for many reasons. Concerning the studied problem, it traces back the story of the question: Cajetan's commentary is quoted and used as a model to respond to Scotus' objections; no mention is made of Javelli. Be this as it may, the form of the commentary is synthetic and different from Cajetan's. Although there is no mention of them in Aquinas' text nor in Cajetan's commentary, in the «unica conclusio» which follows the question 84 (article 7), for example, Báñez introduces the two «Scotist» theses:

${ }^{40} \mathrm{Cf}$. Merinero, De anima, lib. III, disp. IV, q. II, §11, p. 374: «E contrario vero Iavellus 3 de anima quaest. de obiecto possibili, quem communiter recentiores Thomistae sequuntur, asserit, secundum D. Thomam intellectum nostrum ex natura sua se extendere ad omne ens (...).»

${ }^{41}$ See Domingo Báñez, Scholastica commentaria in primam partem angelici doctoris S. Thomae, Salamanca, 1584-1588. We use the edition of Douai, 1614 [apud Petrum Borremannum Typographum Iuratum]. For this text's edition, see D. Báñez, Tratado sobre el hombre. Comentario a Suma teológica, I, q. 75-q. 77, Introducción y notas de J.A. García Cuadrado, Traducción de A.C. Chacon, M. Idoya Zorroza y J.A. García Cuadrado, 2 vols. Pamplona, EUNSA, 2007, vol. I, p. 15-16.

${ }^{42}$ For example, by Mastri and Belluto in their commentary on Scotus' De anima. 
Obiectum adaequatum intellectus nostri secundum totam suam latitudinem sive obiectum specificans est ens in communi: obiectum vero proportionatum et connaturale illi pro statu praesentis vitae, est quidditas rei materialis. ${ }^{43}$

How can this double solution - that the Scotists will acknowledge as inspired by their master - cope with an «orthodox» and consistent reading of Aquinas?

In question 84 , a. 7 , the focus is the functioning of the human intellect and its necessary dependence on the sensitive faculties (the "conversio ad phantasmata»). Báñez claims that the Aristotelian sentence according to which the human intellect always needs the phantasms was common among the Theologians; ${ }^{44}$ why then was Aquinas «attacked» by many of them, concerning the claim that the essence of material being is the human intellect's first object? ${ }^{45}$ Scotus' objections can be quickly summarised in the thesis on the quidditas rei materialis as adequate object is too narrow and does not describe all the intellective functions. Báñez starts off with underlining the double nature of the human cognitive power; despite its union as well as its dependence on the material body, the human intellective power is immaterial and functions differently from the vegetative and the sensitive powers. It has thus a double cognitive first object:

Obiectum intellectus nostri est duplex: alterum quod dicitur motivum, alterum vero, quod vocatur terminativum. Obiectum vero terminativo est illud, ad quod se extendit virtus ipsius potentiae. De obiecto motivo communis sententia est Theologorum et Philosophorum, quam etiam docet Scotus in I. d. 3 q. 3, quod illud est quidditas rei materialis. (...) de obiecto terminativo intellectus nostri possumus loqui dupliciter. Aliud enim est obiectum adaequatum intellectus nostri in tota sua extensione, tam respectu cognitionis perfectae quam imperfectae, tam respectu cognitionis eius, dum est in corpore. Quod alias a Metaphysicis solet appellari obiectum specificans, sive obiectum adaequatum, et hoc obiectum est ens sive verum (...) aliud obiectum intellectus est, quod vocatur proprium et connaturale et proportionatum, quod tantum terminat cognitionem perfectam nostri intellectus, et hoc obiectum non potest esse aliud, quam quidditas rei materialis. Et D. Thom. in hoc artic. tantum loquitur de obiectum intellectus nostri hoc secundo modo. ${ }^{46}$

Báñez acknowledges that in the question he is commenting on, Aquinas had only described the case of the human intellect's proper and connatural object; nevertheless, he takes the thesis on being as obiectum terminativum from two other passages of the Summa, namely Ia q. 5 a. 2 and q. 87 a. 3 ad primum, thus presenting in his commentary

${ }^{43}$ Báñez, In Primam, q. 84, a. 7, unica conclusio, p. 383.

${ }^{44}$ Cf. Báñez, In Primam, q. 84, a. 7, p. 382: «Sic autem moderata haec prima conclusio, est communis doctrina Theologorum et Philosophorum, imo est expressa sententia Arist. 3. De anima, text. 30. ubi expresse docet, quod anima nigil intelligit sine phantasmate.»

${ }^{45}$ Namely by Scotus; Báñez uses Cajetan's synthesis of the Scotist objections as a pattern. Cf. Báñez, In Primam, q. 84, a. 7, p. 382: «Rationem divi Thomae in hoc articulo multi calumniantur, etc.»

${ }^{46}$ Báñez, In Primam, q. 84, a. 7, p. 382-383. 
a more comprehensive synthesis of Aquinas' thought on the problem of the adequate object. Such a synthesis is not present in Cajetan's commentary ad locum and opens at a wider reading of Aquinas' text. Although Báñez agrees with Cajetan's, and states that the human intellect's object is unique and subordinate, in its every cognitive process, to the essence of material being, importantly he also adds, quoting q. 87 a. 3, that the intellect's first object is «somehow common» («commune quoddam»):

Et apertius infra q. 87 articu. 3 ad primum docet, quod obiectum intellectus nostri est commune quoddam, videlicet, ens et verum, non tamen obiectum primum. Nam primum obiectum intellectus nostri secundum presentem statum, non est quodcunque ens aut verum, sed ens et verum consideratum in rebus materialibus, quibus mediantibus in aliorum cognitione devenit. ${ }^{47}$

This elucidation aims to explain how the human cognition is articulated. The human intellect's whole cognitive range is provided by the material substance, which it knows as «quidditative» and directly. God and the angels instead are not the human intellect's first object, they are not known as quidditative, but always through analogy with the material things ("per comparationem ad res materiales») ${ }^{48}$. The fact that the intellect's cognitive object is common makes possible the communication between the cognition acquired directly from the senses, and the cognition extracted by them, indirectly. Hence, just like Cajetan did before, Báñez claims that the human intellect's object, «motivum» and «terminativum», cannot be but the essence of the material substance:

Omnis cognitio intellectus nostri vel terminatur ad res materiales, vel terminatur ad res immateriales medijs materialibus, ergo semper quidditas materialis est obiectum terminativum intellectus nostri, et ex consequenti est obiectum proprium et connaturale. ${ }^{49}$

In his commentary, Báñez presents an «extended» synthesis of the problem, considering the Scotist objections as well as Cajetan's text to build his own. As we have seen, he includes in the discussion other texts by Aquinas in order to defend him from his opponents. Differently from Cajetan, in his «unica conclusio» he distinguishes the human intellect's adequate object in the present state (material being) and in general («ens»). Being in general exceeds the human intellect's proportionate object but

${ }^{47}$ Cf. Báñez, In Primam, q. 84, a. 7, p. 383. Cf. Aquinas, Ia, q. 87, a. 3: «Ad primum ergo dicendum quod obiectum intellectus est commune quoddam, scilicet ens et verum, sub quo comprehenditur etiam ipse actus intelligendi. Unde intellectus potest suum actum intelligere, sed non primo: quia nec primum obiectum intellectus nostri, secundum presentem statum, est quodlibet ens et verum; sed ens et verum consideratum in rebus materialibus, ut dictum est; ex quibus in cognitionem omnium aliorum devenit.»

${ }^{48}$ Cf. Báñez, In Primam, q. 84, a. 7, p. 383: «(...) Deum et substantias immateriales non possumus cognoscere in statu praesentis vitae nisi per remotionem vel comparationem aliquam ad res materiales.»

${ }^{49}$ Báñez, In Primam, q. 84, a. 7, p. 383. 
furnishes it with its whole cognitive range. Báñez also remarks that, whatever the intellect knows, it knows it «sub ratione entis»; ${ }^{50}$ he does not mention, as explicitly as Cajetan did, that every being can be accessible to it after the intervention of grace. The beatifical state is referred to within the argument on the «naturality» of the need of the phantasmata. ${ }^{51}$

Báñez's presentation concerning the studied problem almost represents a standard in the Thomists' commentaries of his day. Despite of the Dominican's engagement in fighting them, we find it, more or less in the same words, even in the commentaries by Jesuits of the calibre of Suárez (De anima, 1572) or Toledo (De anima, 1574). The use of the two theses concerning the intellect's first object does not betray Aquinas' text, but widens the discussion and is somehow part of the strategy to reply to Scotus - and the Scotists' - objections.

\subsection{Zumel}

The other authors whose texts we shall examine are yet another «summista», the Mercedarian Francisco Zumel (1540-1607), as also the famous Discalced Carmelites of the Collegium Complutense. Their commentaries - on the Prima and on De anima testify how the problem of the intellect's first and adequate object was synthetized and, moreover, how Báñez's reading was common among Aquinas' commentators of that day. Just like Báñez, Francisco Zumel, who also lived and worked in Salamanca, uses the «two theses» in his commentary on the Prima Pars. Zumel does not comment on question 84: his commentary comprehends the first 48 questions of the Prima only. The theme of the intellect's first object is thus confronted by the author in question 12, a. 4, which focuses on the impossibility, for the created intellect, to know God's essence by nature and, consequently, on the intellective capacity as well. Following Aquinas'

${ }^{50}$ Cf. Báñez, In Primam, q. 84, a. 7, p. 383: «(...) notandum, quod obiectum alicuius potentiae est duplex. Aliud formale, quod nihil aliud est, quam id sub cuius ratione obiectum refertur ad potentiam, et id in intellectu, est ens sive entitas, omnia enim quae intellectus intelligit, intelligit sub ratione entis. Aliud est obiectum materiale, id est, id, in quo reperitur ratio formalis obiecti obiecti talis potentiae, ut albedo est obiectum materiale visus. Et huiusmodi obiectum, in quo scilicet, principaliter et proportionate reperitur ratio entis, quod est obiectum formale intelectus nostri, est quidditas rei materialis. Itaque quidditas rei materialis est obiectum materiale intellectus nostri proportionatum illi pro isto statu.»

${ }^{51}$ Cf. Báñez, In Primam, q. 84, a. 7, p. 384, ad quintum: «Ad quintum argumentum respondetur ex doctrina eiusdem Caietani, quod intellectum animae unitae corpori passibili indigere conversione ad phantasmata, est naturale; propterea quod eiusmodi intellectus non potest directe cognoscere singularia naturaliter loquendo. Quapropter etiam in statu innocentiae indigebat eiusmodi conversione ad phantasmata. Ad vero quod anima uniatur corpori impassibili et glorioso; est omnino supernaturale, et inde fit quod anima perficiatur in modo etiam intelligendi (...) elevatur enim tunc anima quodammodo ad modum cognoscendi angelorum.» 
pattern, Zumel subscribes, from the very beginning of the discussion, to the proportion principle: the way a cognitive faculty knows something is determined by its own nature.

Cuiuslibet cognoscentis cognitio debet esse secundum mensura naturae. ${ }^{52}$

In the synthesis preceding his commentary, the theologian recalls Aquinas' conclusions. Just like every other created mind, the human intellect cannot see God's essence by nature, namely out of grace; God actually exceeds the nature of every created mind, and the human intellect's adequate object is material being:

Connaturale est animae rationali dum est in via, cognoscere quidditates rerum materialium: non item spiritualium. ${ }^{53}$

Faithful to the principle that to every mind corresponds a proper object, Zumel concludes that the human intellect's adequate object is material being - and the angel's, immaterial being..$^{54}$ The intellect «in via», united to the body, always needs the sensible species and his cognitive departure point is, clearly, material being. Be this as it may, being in general, «simpliciter», and «absolute», is the intellect's adequate object. Thus, there is, on the one hand, the intellect's proportionate object, material being, and on the other hand, there is being in general, that is, «absolute», the intellect's adequate object:

Intellectus humanus, quamvis habeat pro obiecto proportionato quidditatem rei materialis, tamen obiectum adaequatum, est ens secundum suam latitudinem: quod includit, quamvis in confuso et imperfecte illud ens, quod est per se subsistens, et ipsum esse. (...) loquendo de obiecto naturaliter et quidditative cognoscibili, res materialis est obiectum adaequatum naturaliter nostri intellectus: absolute tamen et simpliciter, non est obiectum adaequatum, sed ens..$^{55}$

Zumel's commentary is structured around Scotus' objections and aims to reply to them. ${ }^{56}$ The theological famous argument of the Ordinatio, according to which not even the blessed soul could see God in the afterlife, if one accepts that material being is the intellect's adequate object, is solved through the intervention of grace. The difference between the Scotist and the Thomist account thus consists of the necessity of the divine

${ }^{52}$ Francisco Zumel, In Primam D. Thomae partem commentaria, Venetiis, apud Floravantem Pratum, 1597; in Ia, q. 12, a. 4, p. 195.

${ }^{53}$ Zumel, in Ia, q. 12, a. 4, p. 195.

${ }^{54}$ Cf. Zumel, in Ia, q. 12, a. 4, p. 196-197: «Anima vero non potest cognoscere, nisi quidditates rerum materialium et sensibilium conceptu absoluto. Angeli vero, naturaliter et evidenter solum possunt cognoscere formas a materias separatas, hoc est, intelligentias ipsas: quae similem essendi modum habent cum angelo, quatenus immateriales sunt. Et quoniam Deus est actus purus, cuius essentia est ipsum esse infinite separatum a potentialitate, solus Deus per naturam potest naturaliter cognoscere et comprehendere se ipsum: quoniam obiectum cognitum, est simile et proportionatum naturae cognoscenti, quae est ipse Deus.»

${ }^{55}$ Zumel, in Ia, q. 12, a. 4, p. 197.

${ }^{56} \mathrm{Cf}$. Zumel in Ia, q. 12, a. 4, p. 196 etc. 
intervention («divinitus» ${ }^{57}$ ) to accomplish the beatifical vision. Zumel also specifies that Aquinas did not mean that the intellect cannot know God: the point is how it can know Him. Aquinas denied that the intellect - every intellect - can know God's essence «clare et distincte» by nature; the sole cognition it can get through its «vires», and by nature, is «in confuso et imperfecta», and obtained through analogy: through the cognition, «obscura et confuse», of being in general, that also comprehends God and the immaterial substances. Univocity or analogy are not mentioned by Zumel, who focuses instead on the cognitive subject's nature, thereby closely following the text is commenting on. ${ }^{58}$ The «radix modi cognoscendi», is the nature of the cognitive faculty.

Zumel's text, which we have quickly examined, is very clear, and summarises the main concepts of Aquinas' account in a very effective synthesis. Nature and proportion determine the kind of cognition of the intellective power; the "two theses» on being are mentioned in the wake of the replies to Scotus' arguments.

\subsection{The Complutenses}

The last paragraph of this section is devoted to the De anima commentary published by the Discalced Carmelites of the College of Alcalá (1637)..$^{59}$ This text was also counted by the Scotists among the Thomistic commentaries «following Scotus», namely, exposing the two theses on the intellect's adequate object, absolute and in via ${ }^{60}$. This scholastic work, which summarises the Thomist tradition, makes use of the same pattern employed in the commentaries on the First Part by Báñez and Zumel. Being a commentary On the Soul, and not on the Prima, it adds to the original Aristotelian structure the problems and the issues brought up by the medieval and Renaissance tradition. The reference to Aquinas, the tutelary deity of the Carmelites' Cursus philosophicus, is clear. On the intellect's first object, in the disputatio 17 the first question is concerned with the thesis of being in general, and the second, with material being:

${ }^{57}$ Cf. Zumel, in Ia, q. 12, a. 4, p. 197: «(...) ut intellectus noster intelligat quidditatem immaterialem, necesse est ut divinitus adiuvetur et confortetur.»

${ }^{58}$ Zumel, in Ia, q. 12, a. 4, p. 197: «Quantum ad modum essendi, qui est radix modi cognoscendi, verbi gratia rationalis anima quandiu habet modum essendi unita corpori ut forma, non potest cognoscere Angelum naturaliter sicuti est. Quia cognitio animae in tali statu, non est sine conversione ad phantasma corporale: et ita naturaliter non potest evidenter cognoscere, nisi quidditatem in materia.»

${ }^{59}$ Cf. Collegium Complutense (Discalceatorum Fratrum Ordinis B. Maria de Monte Carmeli), Disputationes in tres libros Aristotelis de Anima. Iuxta miram Angelici Doctoris D. Thomae, et Scholae eius doctrinam, Lugduni, 1637. The author of this work is Antonio de la Madre de Dios (Antonius a Matre Dei, 1583-1637), active in Alcalá and Salamanca. On this text, see Jansen, B., «Zur Phänomenologie der Philosophie der Thomisten des 17. Und 18. Jahrhunderts», Scholastik, 13, (1938), pp. 49-71; Spruit, L., Species Intelligibilis. From Perception to Knowledge, Vol. 2, Renaissance Controversies, Leiden, Brill, 1995, pp. 334-337.

${ }^{60}$ For example, by Mastri and Belluto: see n. 34 . 
Dicendum tamen est obiectum adaequatum nostri intellectus esse ens, aut verum in tota sua latitudine. Ita D. Tho. I p. q. 84 , art. 7, ad tertium et q. 87 art. 3 ad primum, ubi loquendo de obiecto intellectus nostri sic ait: Dicendum quod obiectum intellectus est commune quoddam scilicet ens. Et verum sub quo comprehenditur etiam ipse actus intelligendi. Si autem ens non in tota sua latitudine, sed ut restringitur ad ens e verbi gratia naturale, esset obiectum nostri intellectus, non dixisset, absolute, ens esse obiectum illius, sed addidisset ly naturale, sicut quia obiectum Philosophiae non est idem ens in toto suo ambitu, sed limitatum ad ens mobile; (...). ${ }^{61}$

The same texts of the Prima are mentioned in reference to the second thesis, that concerning the intellect's adequate object in the present state:

Dicendum est primo, intellectum pro hoc statu habere pro obiecto proportionato solam quidditatem materialem, ac proinde, solam eam, ut abstractam a conditionibus materialibus individuantibus. Ita Aristot. in hoc lib. text. 8 quem D. Thom. loquens ibidem lect. 8 de obiecto proportionato intellectus pro hoc statu (...) Quod etiam docet quaest. 87. art. 3 ad primum eumque communiter sequuntur Caietanus, 3 de Anima cap. 5, Bañes I. part. quaest. 84. art. 7. dub. I. referens omnes discipulos S. Doct. nec non, et Scotum in I. distinc. 3. quaest. $3 .^{62}$

\subsection{Early Modern Readings}

This overview of Thomist and Scotist texts, concerning the intellect's first object, has no pretention to be exhaustive, nor to establish what Aquinas or Scotus really said about it. My aim was only to show how, between the $16^{\text {th }}$ and the $17^{\text {th }}$ centuries, Aquinas' account on the primum cognitum exposed in the Prima Pars was read and exposed in the scholastic production of that day. The Scotists, as we have seen, criticised Aquinas' account of cognition through different strategies. In his Collationes Macedo reduces Aquinas' theory to a fragmentary puzzle, that none among his followers had been able to recompose. Macedo's strategy is that of separating Aquinas' texts, isolating them, and thereafter showing their disharmony and incoherence, compared to Scotus' account. The second criticism, vehiculated, as we have seen, by some among the most important Scotists of the $17^{\text {th }}$ century - Fabri, McCaghwell, Mastri and Belluto - aims instead to show that Scotus' thesis concerning the studied problem was better than Aquinas' in another (more subtle) way: at a certain point, the Thomist Javelli started to account for the intellect's first object problem just like Scotus did, basically attributing to Aquinas the same two theses of the Ordinatio: "pro statu isto", in the present state, and «absolute», in general. Such a reading, the Scotists claimed, does not correspond to what Aquinas affirmed. The thesis of being as first cognitum was perceived, by them, as stolen directly from Scotus.

\footnotetext{
${ }^{61}$ Collegium Complutense, De anima, disp. 17, q 1, §3, n. 4, p. 379.

${ }^{62}$ Collegium Complutese, De anima, disp. 17, q. 2, §1, n. 24-25, p. 386.
} 
What can we derive from this overview of texts? Did the Thomists change, as the Scotists claimed, their reading of Aquinas in the wake of Javelli? Or was Javelli right, when he claimed that Scotists and Thomists were fighting around terms, more than sense («potius verbis quam sensu»)? ${ }^{63}$ If, as we have seen, Macedo tried dismantling Aquinas' theory into fragments - portions of text, taken out of their context -, my impression is that early modern Thomists aimed to recompose the puzzle proposing, in their readings, a more comprehensive picture of Aquinas' account of cognition. The thesis on «ens» as adequate object is derived from Aquinas' texts, and meticulously put alongside that on material being in order to reply to the Scotist accusations. In his commentary, Cajetan focused on the thesis exposed in the quaestiones 84, 85 and 86, and stated that, according to its nature, the human intellect's first object is material being; being in general, is known through material being, as «arrival point» (obiectum terminativum) of the cognitive act. This thesis is highlighted in their commentaries by the early modern Thomists, of every kind and order: from the "Thomista rigidus» Domingo Báñez to the Jesuits Toledo and Suárez, and the Carmelites of the Collegium Complutense.

Anna Tropia

anna.tropia@gmail.com

Fecha de recepción: 09/07/2019

Fecha de aceptación: 15/09/2019

${ }^{63}$ Cf. Javelli, De anima, lib. III, q. 2, p. 179 (cf. n. 26). 
